\title{
Global Cities, Global (in)Securities: An Introduction
}

Cidades Globais, (In)Seguranças Globais: Uma Introdução

\author{
Thiago Rodrigues* \\ Fernando Brancoli ${ }^{* *}$ \\ Paul Amar ${ }^{* * *}$
}

\section{Urban territories, contemporary conflicts}

The urban landscape is already the main center of social interaction in the globe since the vast majority of the world's population inhabit cities. As the core of contemporary social life, urban areas concentrate most of the conflictive encounters opposing a great variety of actors. From small villages to major 'Global Cities' (Sassen 1991, 2005) and impressive megacities, urban space constitutes the main field in which political and economic endeavours take place. Therefore, it is not surprising that most of the crucial and more violent conflicts of our age occur in urban areas.

It is true that cities and violence have a long and common old history (Ashworth 1991). Across the globe, and since ancient ages, cities have been the stage for protection as well as for pillage, massacres, upheavals, starvation, and military sieges. In Europe, cities had a crucial role in the process in which Modern States emerged. Then, fortified cities gave way to overpopulated urban spaces while the political, legal and military limits expanded until they were established along national borders (Tilly 1990). The emergence of interstate/international relations, as an immediate reflection of the political power centralisation within the states, was accompanied by the elaboration of sophisticated legal and political-philosophical discourses that justified the existence of the state as the only entity capable of keeping internal peace and order in a troubled world (Neocleous 2014; Foucault 2003; Rodrigues forthcoming). However, the violent and tumultuous history of the nation-state is also the history of conflict and struggle within urban spaces.

In the nineteenth century, the emergence of the so-called 'total war era' (Keegan 1993) transformed industrial cities into strategic sites in which the vast majority of economic,

\footnotetext{
* Fluminense Federal University (UFF), Niteroi-RJ, Brazil; trodrigues@id.uff.br. ORCID iD 0000-00020962-0391.

** Federal University of Rio de Janeiro (UFRJ), Rio de Janeiro-RJ, Brazil; fbrancoli@gmail.com. ORCID iD 0000-0003-0429-2154.

*** University of California, Santa Barbara-CA, United States; amar@global.ucsb.edu. ORCID iD 0000-00016113-3227.
} 
political and military assets were concentrated. This new reality called once more the urban spaces to the center of the most important security problems and events. In the late nineteenth century and early twentieth century, while a new-born humanitarian law was trying to separate civilians from military in war times, cities and their population became living targets. The ancient practice of 'urbicides' - the complete destruction of cities and their inhabitants - re-entered the scene, especially since World War II, as the tragic memories of Hamburg, Berlin, Hiroshima, Stalingrad, and Nagasaki certainly demonstrate (Shawn 2004).

Nonetheless, since the 1940s, the connection between cities and conflict has sensibly changed, going beyond the destructive effects of interstate warfare. Both in the industrialised metropolises in the North and in the new Southern metropolises, conflicts arose related to a vast array of struggles such as the colonial rebellions, resistances against authoritarian regimes, and multiple forms of security policies toward social groups such as ethnic minorities, impoverished populations, and religious groups among others.

It is mainly in city spaces where clashes that Frédéric Gros (2010) calls 'states of violence' occur. A new rationale for organised violence different from the classic interstate warfare, the 'states of violence' mobilise non-state actors - such as criminal gangs, mafias, and militias - as well States' repressive forces in brushed-up forms of conflict that do not have legal parameters, defined temporalities or clear identities for contending forces. In this context, phenomena such as drug trafficking and terrorism emerge as transterritorial flows that find bases to act, exist, and to reproduce in urban spaces.

The contemporary urbanisation of warfare produces what Graham (2010) called 'urban militarism', a process in which the presence of a whole plethora of security technology devices establishes a daily experience of control. Through the employment of equipment such as GPS transponders, surveillance cameras, electric fences, private security companies articulate themselves with a transformation of police and military forces in an increasingly indistinct type of urban-military coactive corporation. In urban spaces, the 'policialisation of the military' meets the 'militarisation of the police' (Neocleous 2014; Rodrigues 2015). More than that, the 'new urban militarism' instates a never-ending process of enemy-production within urban spaces, as well as volatile borders which recreate in the local level the inside/outside duality previously attached to the distinction between national/international territorialities (Graham 2010).

Thus, it is possible to identify, both in the Northern and within the Global South's urban areas, various 'security archipelagos' (Amar 2013) composed by different segregated ambiences: ghettos, luxury apartments, business towers, slums, and decrepit downtown areas. Each one of these urban spaces produces and reproduces distinctive identities that reinforce social stigmas and political, as well as security, practices of 'otherness'. These parts of the cities live in constant tension, managed by security apparatuses, both private and public, undergoing an urgent imminence of irruption in violence (Wacquant 2008, 2009). Cities are under surveillance by the combination of many different confined spaces and technologies of open-air control such as video cameras, satellites, and a broad range of electronic devices previously developed for military use. Henceforth, cities, each converted into a 'phobopolis' (Souza 2008) - 'cities of fear' - are urban spaces opened for 
many types of control, repression, coactive urbanisation policies, as well as a stage for new political experiences and novel forms of rebellion (Amar 2013; Harvey 2012).

Since the 1990s, the deepening of non-conventional conflicts and the centrality of urban spaces in this scenario has provoked the engagement of scholars from different fields such as critical security analysts, urbanists, sociologists, historians and anthropologists interested in understanding the ruptures and continuities in the ancient relationship between cities and warfare. For instance, cities have become a special object for analysis in global studies, including specialised literature on security. The studies on violence in urban areas has influenced various research among several methodological and epistemological apparatuses such as critical urban studies (Graham 2004a, 2004b, 2010), criminology (Maltz, Gordon and Friedman 2000; Mears and Bhati 2006), sociology of violence (Gotz and Heim 2002) and radical analyses of control and identification (Bigo 2008).

Despite increasing interest in the role and place of cities within contemporary forms of violent armed conflict, this complex issue has attracted little attention among International Relations scholars when compared to other issues such as interstate warfare or even phenomena such as terrorism, refugees flows and drug-trafficking realised in urban spaces. For Graham, however, the importance of urban spaces to understand contemporary world politics 'forced, for the first time, [international relations theorists] to consider urban and sub-national spaces as crucial geopolitical sites' (2004: 52). This Contexto Internacional Special Issue intends to contribute for bridging this gap by gathering different theoretical, methodological and epistemological perspectives and distinctive subjects for analysis, which have in common their interest in making sense of the centrality of urban space in contemporary global politics through International Relations lenses. Those lenses focus on the various processes of violence and conflict that have erupted within Global South urban areas, mixing analyses of particular cities with theoretical reflection that take contemporary urban warfare as a grip for developments on security studies.

\section{Production of (in)security in urban spaces}

The capacity to control urban space means holding down power which, in turn, implies a capacity for controlling societies and groups. Dominating the production of the urban, therefore, means possessing important and potential instruments for social control. In this sense, Lefebvre (2003) affirms that space has a fundamental characteristic, which is to be politically instrumental. Throughout history, this dimension will be more or less disguised through justifications that guarantee an apparent neutrality in the execution of certain public policies.

Hereupon, it is possible to highlight several moments of significant relevance in which different political strategies over public space were used as instruments for control and domination of cities and their populations. For example, the urban reforms of Paris conducted by Georges-Eugène Haussmann between 1852 and 1870, resulted in the creation of large and linear boulevards with the aim of extinguishing the narrow alleyways that prevented Napoleon III's armies from dominating territory and that facilitated the creation of barricades and other forms of resistance during the revolution of 1848 (Hall 
1995). From a similar perspective, also based on a hygienist bias, it is possible to highlight the reforms carried out by colonial powers over subjected cities such as the Europeanisation of Cairo in the 1860s (Amar 2013); or the co-active urban reform enforced in Rio de Janeiro, between 1903 and 1906, which meant to transform the old colonial city in a Parisian-like modern capital (Abreu 1987).

Ferreira (2007) points out that the production of urban space is unequal, since it is associated with capitalist social production that is (re)produced unevenly. In this regard, urban space holds particular importance to the development of networks of society capable of reacting to the manifestations of the forces that has been controlling the city. According to Bauman (2006), public places are the crucial points in which the future of urban life is decided at this time. In the context of urban planning history, public space, especially the streets and sidewalks, were at times neglected or underutilised.

From the end of the nineteenth century to the 1960s, violent urbanism in Europe and in the United States established new standards for controlling urban spaces and population that were applied in colonial and postcolonial cities. Experiences developed for postcolonial cities were, also, translated to industrialised Northern cities in a boomerang effect that connected North and South in the development of governmental practices of territories and population (Graham 2010). Since the 1960s and 1970s, critics and reformists called for attention to the importance of urban space as a place for the generation of diversity with the multiplicity of uses of the urban territory being a central element for the integration of its inhabitants (Jacobs 1992). However, the criticism on urban segregation and the multiple violence related to the control of city areas coincided with the emergence of neoliberal policies that invested in new modes of urban planning which have been producing the contemporary forms of ghettification both of impoverished population and of economic elites. In this context, urban spaces have become places of (in)security and the territory for the most threatening fears such as the attempts against personal life and property, the commerce and use of illegal drugs and the attacks of terrorists. The discourses on urban (in)security are part of a broader production of discourses on security upon which governmental policies are built.

Understanding the production of (in)security elements as a way of controlling urban space is ultimately inscribed in the control of significant elements of individuals' lives. Thus, the determination of spaces and, especially, which social characteristics are accepted or not, are operationalised within what Michel Foucault (1978) determined as biopolitics, the set of governmental tactics directed to the control of population life (its dynamics, its spaces, its flows through the territory). Within this perspective, the discussion about the re-standardisation of what can be understood as the urban space fit into an even broader dynamic, since biopolitics is not only directed at trying to control biological life, but in actually organising and promoting certain modes of life, work, political participation and so forth. In this process, the 'dangerous classes' (Foucault 2003), or the portion of the population not useful for the prevalent economic and political order must be controlled and confined. Mark Duffield argues that biopolitics is the combination of social welfare with social control in the sense of 'restricting or managing the circulation of potentially 
threatening or incomplete lives' (2008: 51). For the non-profitable bodies, it is necessary to erect material or symbolic barriers.

Loïc Wacquant (2009) identifies in our neoliberal era the emergence of what he calls the 'new governability of social insecurity' as a centralising apparatus for the administration of society, especially of the poor, in order to shape behaviours for a particular economic order. Thus, this regime would integrate mechanisms of penal control and spatial occupation to contain forms of marginalisation associated with neoliberal processes such as deindustrialisation. In this sense, it would be the attempt of certain state forces to manage the growing isolation, poverty and endemic insecurity of the city, in a regime of governance that emphasises its logic in the non-stop production of enemies. The urban space is the locus in which took place this battle to control and to govern people and territory.

The discourses of public safety as an element to perform urban transformation is echoed in what Kipfer and Goonewardena (2007) call 'urbicide' (also see Shawn 2004), which means the political violence condensed to specifically annihilated urban spaces, but focusing on areas containing individuals perceived as threats to the established order. Although the authors in question used the terms to analyse cases in the Middle East, such as the electrification process of Iraqi Kurdistan, the notion could travel beyond this particular region to include urban areas around the world.

Within this logic, 'the struggle for the city now coincides more and more with the dispute for the social order' (Graham 2010: 241). These two concepts, especially in the indication of areas and individuals that must be remodeled or excluded, can be combined with a third element, the practices of exception, which gives a broader understanding of how material and symbolic violence serves as a parameter to analyse the occupation, controlling and securitisation of cities' spaces. The Modern parameter for the creation of 'otherness' - the national against the international/foreigner (Walker 1993) - has been partially substituted for other forms of duality that express themselves within urban scenarios, from European and US's ghettos to Latin American, African and Asian megalopolises with their slums and luxury condos. The official discourses such as the war on terror and the war on drugs identify 'enemies' inside the cities and across urban areas and national borders. Meanwhile, neighbourhoods have been isolated or controlled by state forces, private militias, and criminal organisations. Different kinds of governmental practices overlap competing for territorial control and the pacification of certain social groups. The military occupy urban areas both in North and Global South cities, while mafias and local gangs oscillate between co-operation and competition for urban spaces. Warfare is within urban spaces, where the vast majority of people live, struggle and die violently in the contemporary world.

\section{Urban conflicts, multiple lenses}

This Special Edition for Contexto Internacional puts together a broad yet complex panel of contemporary security issues related to urban areas in the world, focusing on the Global South's urban areas. We understand that the urban phenomenon, particularly in its security elements, compounds a global subject worthy to be studied through an international 
lens, especially under a critical security perspective. We managed to gather original research outcomes on urbanisation projects and urban security programs justified to control, secure or integrate urban areas, as well pieces on the contemporary modalities of urban warfare and their impacts on global security. From different perspectives, the articles that compound this dossier address relevant and provoking questions on urban conflicts.

The first work of the series is the article 'Militarising Mumbai? The "Politics" of Response. Mumbai Must be Secured. Now!' by Rhys Machold who points out how Mumbai, India, dealt with urban security practices after the terrorist attacks of 2008. Machold's main argument is that the Mumbai case reveals how practices of urban space securitisation can also be understood in terms of theatrical and spectacular manifestations, which reinforce strategies of government and control over urban areas in a close communication between global strategies - such as the war on terror - and local strategic, political and economic interests.

Machold's reflection is followed by Manoela Miklos' and Tomaz Paoliello's 'Fragile Cities: a Critical Perspective on the Repertoire for New Urban Humanitarian Interventions' in which the authors examine how the discursive apparatus connected to concept of 'failed states' was exported to cities, articulating the normative and practical consequences. In this sense, they argue that the notion of 'fragile city' is a groundbreaking tool for understanding the human consequences of inequality in urban settings, but might also be used as a rhetorical vehicle for the reproduction of old dynamics of intervention. From a critical perspective, Miklos' and Paoliello's article dialogues with Machold's when reflecting about how the production of security concepts is a crucial movement in order to define 'enemies' in the context of the so-called global war on terror, and how interconnected are the local and the global dimensions of securitisation practices.

The two following articles reinforce, from distinctive perspectives and subject analysis, how the articulation between global and local security issues operate within urban spaces. First, Silvia Roque's 'Between New Terrains and Old Dichotomies: Peacebuilding and the Gangs' Truce in El Salvador' presents an original study of the truce negotiation in El Salvador between the state and several criminal groups. Roque argues that a peacebuilding framework, inspired by a set of critical perspectives on war and peace and on the nature of 'the political', is of central importance for the future of policies aimed at curbing violence in the Global South. The article opens an interesting discussion on the limits and possibilities of international practices of peacebuilding under the United Nations' flag and from other processes of political transition in offering applicable standards to solve local conflicts. In the Salvadorian case, the process must face its urban nature in order to be analysed and addressed.

Later, Joana Castro Pereira and Miguel Rodrigues Freitas focus on a global issue that is one of the most important bases for contemporary conflicts: the question of potable water and the control over its sources. In 'Cities and Water Security in the Anthropocene: Research Challenges and Opportunities for International Relations', the authors display the main problems related to the use and scarcity of water in the world and how this issue impacts in urban settlements and its conflicts. Through this angle, Pereira and Freitas indicate how local and global spheres are connected as never before, generating 'glocal' 
issues. In this context, they focus on the role of water as a component to understand the role of cities in the contemporary world and why International Relations needs to include theoretical and methodological approaches that can cope with non-traditional themes in order to sustain its contribution to global security.

Next, the dossier focuses on different Latin American issues. Gilberto M A Rodrigues and Thiago Mattioli indicates how the sub-national levels and regional instruments for co-operation are interconnected and how they are increasingly important to understand the ways the security problematique is being addressed. Taking the case of the consultation groups on public safety produced within the network called Mercocities, the authors present the originality of this experience, as well as its limitations when national security agencies struggle to monopolise the power to operate and to enforce security policies. The article 'Paradiplomacy, Security Policies and City Networks: the Case of Mercocities' Citizen Security Thematic Unit (2004-2015)' is, also, an interesting reflection on how concepts such as 'citizen security' and 'human security', produced by extra-regional agencies and scholars, can influence local policies and governmental practices for the urban space within Mercosur's countries.

The city of Rio de Janeiro and the engagement of the military in order to secure the Olympic Games is Veronica F Azzi's target in the article 'Security for Show? The Militarisation of Public Space in Light of the 2016 Rio Olympic Games'. Azzi highlights the contradictions between the accounts on the collapse in domestic security vis-à-vis official government statements to the international media to assure that everything will be secure during the mega sports event. The author addresses the militarisation of public safety in Rio justified by the Olympic Games as a process that reveals an international connection - aiming to secure the city for foreign investments and based on a globalised anti-terror rhetoric - and local foundations related to Brazilian contradictions toward public safety challenges.

Finally, Thiago Rodrigues, Mariana Kalil, Roberto Zepeda, and Jonathan D Rosen take the Mexican city of Acapulco as a subject in order to exercise a theoretical analysis on the relationship between urban conflict and the dynamics of drug-trafficking in the Americas. In 'War-Zone Acapulco: Urban Drug-Trafficking in the Americas' the authors present the history of Acapulco's illegal drugs economy and its connection with a broader process which encompasses the continental dynamics of drug-trafficking. The hypothesis is that Acapulco epitomises the contemporary (in)security dynamics of the Americas' urban zones where the production of geographical, political and economic borders is exacerbated by the political economy and the geopolitics of drug-trafficking in the Americas, as well as by militarised attempts to combat it.

Thereby, this Special Issue invites for an attentive overview of the relationship between cities and security issues. We selected articles that represent a comprehensive collection of analytical and thematic perspectives related to our main problem. By doing so, we intend to offer various theoretical and methodological approaches to this question that empower our readers to go beyond in their own research questions. We also would defend the relevance of the 'urban problematique' within International Relations academia, in general, and within security studies, in particular. We believe the readers will find a useful 
conjunct of reflections with potential capacity to enlighten further analysis. We would like to thank Contexto Internacional's Editors, peer-reviewers and, especially, the authors for the interest and hard work. We wish our dossier could stimulate innovative and potent studies on the quotidian challenges that defy us along the vibrant, violent and vivid borders and paths of world's urban spaces.

\section{References}

Abreu, Maurício. 1987. A evolução urbana do Rio de Janeiro. Rio de Janeiro: Zahar.

Amar, Paul. 2013. The security archipelago. Durham/London: Duke University Press.

Ashworth, G J. 1991. War and the City. London/New York: Routledge.

Bauman, Zygmunt. 2006. Liquid Fear. Cambridge: Polity Press.

Bigo, Didier. 2008. 'EU Police Cooperation: National Sovereignty Framed by European Security? Security versus Justice?' In Elspeth Guild and Florian Geyer (eds), Security Versus Justice? Police and Judicial Cooperation in the European Union. Aldershot: Ashgate, pp. 150-175.

Ferreira, Álvaro. 2007. 'A produção do espaço: entre dominação e apropriação: Um olhar sobre os movimentos sociais', Revista Electrónica de Geografía y Ciencias Sociales, XI, 245(15). At http://www. ub.edu/geocrit/sn/sn-24515.htm [Accessed on 3 July 2017].

Foucault, Michel. 1978. The History of Sexuality, Volume I. New York: Pantheon Books. Picador. 2003. Security, Territory, Population. Lectures at the College de France 1977-78. New York:

Gotz, Aly and Sussane Heim. 2002. Architects of Annihilation: Auschwitz and the Logic of Destruction. Princeton: Princeton University Press.

Graham, Stephen. 2004a. 'Cities as Strategic Sites: place annihilation and urban geopolitics'. In Stephen Graham (ed), Cities, War and Terrorism: towards an urban geopolitics. Malden: Blackwell Publishing, pp. 31-53.

2004b. 'Introduction: Cities, Warfare, and States of Emergency.' In Stephen Graham (ed), Cities, War and Terrorism: towards an urban geopolitics. Malden: Blackwell Publishing, pp. 01-30.

2010. Cities under Siege: the new military urbanism. London/New York: Verso Books.

Gros, Frédéric. 2010. States of violence: an essay on the end of war. London/New York/Calcutta: Seagull Books.

Hall, Peter. 1995. Cidades do amanhã: Uma história intelectual do planejamento e do projeto urbanos no século XX. Transl. Pérola de Carvalho, Anita Guimarães and Maria Alice Junqueira Bastos. São Paulo: Perspectiva.

Harvey, David. 2012. Rebel Cities: from the right to city to the urban revolution. London/New York: Verso.

Jacobs, Jane. 1992. The Death and Life of Great American Cities. New York: Vintage Books.

Keegan, John. 1993. A History of Warfare. New York: Vintage Books.

Kipfer, Stefan and Kanishka Goonewardena. 2007. 'Colonization and the New Imperialism: On the Meaning of Urbicide Today'. Theory \& Event, 10(2). At https://muse-jhu-edu.ezproxy.library.wisc. edu/article/218089 [Accessed on 3 July 2017]. 
Lefebvre, Henri. 2003. The urban revolution. Transl. Robert Bononno. Minneapolis: University of Minnesota Press.

Maltz, Michael, Andrew C Gordon and Warren Friedman. 2000. Mapping crime in its Community Setting: Event Geography Analysis. New York: Springer-Verlag.

Mears, Daniel P and Avinash S Bhati. 2006. 'No community is an Island: the effects of resource deprivation on urban violence in spatially and socially proximate communities'. Criminology, 44(3): 85-102.

Neocleous. Mark. 2014. War Power, Police Power. Oxford: Oxford University Press.

Rodrigues, Thiago. Forthcoming. Politics is Warfare: Agonism and International Relations. Edinburgh/Oakland/Baltimore: AK Press.

Sassen, Saskia. 1991. The Global City: New York/London/Tokyo. Princeton: Princeton University Press.

2005. 'Global Cities and Survival Circuits.' In D Stanley Eitzen and Maxine Baca Zinn (eds), Globalization: The Transformation of Social Worlds, 2nd ed., Florence, KY: Wadsworth Publishing.

Shawn, Martin. 2004. 'New Wars of the City: Relationships of "Urbicide" and "Genocide". In Stephen Graham (ed), Cities, War and Terrorism: towards an urban geopolitics. Malden: Blackwell Publishing, pp. 141-153.

Souza, Marcelo. 2008. Fobópole: o medo generalizado e a militarização da questão urbana. Rio de Janeiro: Bertrand Brasil.

Tilly, Charles. 1990. Capital, Coercion, and European States - AD 900-1900. Cambridge: Basil Blackwell.

Wacquant, Loïc. 2008. Urban outcasts: A Comparative Sociology of Advanced Marginality. Cambridge: Polity.

2009. Punishing the Poor: The Neoliberal Government of Social Insecurity. Durham: Duke University Press.

Walker, RBJ. 1993. Inside/outside: International Relations as Political Theory. Cambridge: Cambridge University Press.

\section{About the guest editors}

Thiago Rodrigues is Head of Department in the Institute for Strategic Studies (INEST) at Fluminense Federal University (UFF) in Brazil; Communications Director of the Global South Caucus (International Studies Association, ISA); and Director of Institutional Relations of the Brazilian Association for Defence Studies (ABED). He specialises in the study of drug trafficking and International Relations theory. He is also Assistant Editor of the Oxford academic journal International Political Sociology, and co-editor of the books Drug Policies and the Politics of Drugs in the Americas (Springer, 2016), and Drogas, Politica $y$ Sociedad en América Latina y Caribe (CIDE, 2015), among others.

Fernando Brancoli is Assistant Professor of International Security at the Federal University of Rio de Janeiro (UFRJ), Brazil, and a Research Affiliate at the Global Security Hub 
at the University of California-Santa Barbara, USA. He holds a PhD in International Relations from the San Tiago Dantas Program (Unesp/Unicamp/PUC-SP), and has worked at Humanitarian Organisations in North Africa and the Middle East, including the Mercenary Control group at the United Nations. He was a member of research groups at the University Paris I-Panthéon Sorbonne (France), and at the Arab Council for the Social Sciences (Lebanon). His research interests relate to the intersection between Critical Security Studies and post-structural methodological practices, such as ethnographic and discourse analysis applied to contemporary conflicts.

Paul Amar is Professor in the Global Studies Department at the University of CaliforniaSanta Barbara, United States. He is a political scientist, and anthropologist with affiliate appointments in Feminist Studies, Sociology, Comparative Literature, Middle East Studies, and Latin American \& Iberian Studies. He currently serves as Director of the MA, and PhD Programs in Global Studies, and as Coordinator of the Global Security Studies Hub. Before he began his academic career, he worked as a journalist in Cairo, a police reformer and sexuality rights activist in Rio de Janeiro, and as a conflict-resolution and economic development specialist for the United Nations.

Received on 27 June 2017, and approved for publication on 4 July 2017. 